\title{
Contributions to risk assessment in the departments of welding mechanical engineering companies
}

\author{
Gheorghe Amza ${ }^{1, *}$, Dan Florin Nitoi ${ }^{1}$, Valentin Dan Petrescu ${ }^{2}$, Zoia Apostolescu ${ }^{1}$, \\ and Oana Roxana Chivu ${ }^{1}$ \\ ${ }^{1}$ Polytechnica University of Bucharest, Splaiul Independentei, no. 313, sector 6, Bucharest, Romania \\ ${ }^{2}$ Lucian Blaga Universiy of Sibiu, 10 B-dul Victoriei, Sibiu, Romania.
}

\begin{abstract}
The risk assessment professional should cover every activity and every workstation in an enterprise engineering, considering each component of the production system (the system working), each duty, work equipment and working environment. This represents an extremely complicated and complex problem because of production system that is a powerful polluting technology, especially of the atmosphere and soil. The formation of gas welding process is the result of electrodes burning, fluxes, and development of bath fused metal the welded seam. In welding processes, human operators are exposed to smoke and toxic gases, arising from the welding process, which can be dangerous to health. Many acute intoxication caused by to excessive exposure or short exposure to severe smoke and gases resulting from the welding process were studied the course of time. The paper focuses on smoke inhalation and calculate the score of danger each chemical agent score volatility of process. This conducts to collective protection so ultimately results in a score of inhalation $S_{\text {inh }}=1000$, or resulting risk moderate, requiring a set of protective and preventive measures that are proposed in this regard.
\end{abstract}

\section{Introduction}

Occupational risk assessment must cover each activity and each shop of a machine building company, taking into account each component of the production system (work system), every workload, work equipment and work environment. This represents an extremely complicated and complex problem because the production system of such an enterprise is particularly complex and complicated. Involvement of workers from each job and, where appropriate, of their representatives with specific responsibilities in the field of occupational safety and health, and of the Occupational Safety and Health Commission (OSHC) is mandatory in the assessment of occupational hazards, as workers know the most dangerous situations and places at workstations and the OSHC is formed and informed about the dangers specific to the company's activities.

As almost all the production sites of this company meet the welding process * (from design to assembly) [5], this paper will assess the chemical risk through inhalation in this technological process [1-2]. 
Welding assembly is a highly polluting technology process, especially of the atmosphere and soil. The formation of gases in the welding process is the result of electrodes and fluxes burning, forming the molten metal bath, and welded seams developing. Welding operators are exposed to smoke and toxic gases resulting from the welding process, which may be hazardous to health. Many acute intoxications due to excessive exposure or short-term exposure to smoke and gas resulting from the welding process have been studied over time. However, in addition to general effects such as respiratory irritation, long-term effects have been directly attributed. The influence of smoke and toxic gases, for example, the chronic effects due to the presence of chromium, nickel and aluminum. Since in any technological process, the main pollutants emitted in the working environment or the natural environment are chemical substances, the greatest risk that occurs in these jobs is the chemical risk produced by a chemical agent. Regarding chemical risk, the assessment procedure is often difficult because of the many chemical agents and preparations used, as well as the lack of awareness of the dangers they pose.

At work, welding operators may be exposed to hazardous chemical agents, either accidentally (explosions, fires, pipe or tank damage, etc.), or routinely during use, handling or transport. Hazardous chemical agents may cause one or several of the following effects: poisoning, burns, fires, irritations, injuries [3].

\section{Chemical risk assessment}

The chemical risk assessment method for health, safety and the environment is progressive, calls for simple and easily accessible criteria, being a step-by-step approach to optimizing the collection of information on the main chemical agent (MCA) and workload. The method comprises the following main steps:

- inventory of chemical products and materials used in a location, workshop or workstation;

- potential risk management (PRA);

- risk evaluation.

Product inventory is the most important step because it condition the quality of a risk assessment approach. The inventory of chemicals, raw materials, intermediate products should be as exhaustive as possible. The data collected at this stage are:

- chemical name or trade name of the product,

- the quantity used (in the previous months);

- frequency of use;

- the work area where the product is used,

- hazard information on labels (pictograms, risk phrases);

- the information given in the risk phrases (hazards, physicochemical properties).

In the inventory phase, risk phrases are essential aid in this approach.

\subsection{Potential hierarchy of risk (PHR).}

Because of the large number of products and raw materials used in a site, it is necessary to prioritize hierarchy and prioritization to begin with the most dangerous products. The hierarchy of the identified products is done using the PHR method [8]. This takes into account the hazards, the potential exposure (health), the potential for ignition (fire, explosion) and the transfer potential (environmental impact). The PHR method takes into account the criteria presented in Table 1. 
Table 1. Criteria used to calculate the potential risk of a chemical agent [1]

\begin{tabular}{|c|c|c|c|c|c|}
\hline \multicolumn{2}{|c|}{ Effects on health } & \multicolumn{2}{c|}{ Fire explosion } & \multicolumn{2}{c|}{ Environmental Impact } \\
\hline Danger & $\begin{array}{c}\text { Potential } \\
\text { exposure }\end{array}$ & Flammability & $\begin{array}{c}\text { Potential of } \\
\text { ignition }\end{array}$ & Danger & $\begin{array}{c}\text { Transfer } \\
\text { potential }\end{array}$ \\
\hline $\begin{array}{c}\text { Risk } \\
\text { phrases }\end{array}$ & $\begin{array}{c}\text { Used } \\
\text { quantity }\end{array}$ & Used quantity & $\begin{array}{c}\text { Stored } \\
\text { quantity }\end{array}$ & Risk phrases & $\begin{array}{c}\text { Used } \\
\text { quantity }\end{array}$ \\
\hline & $\begin{array}{c}\text { Frequency of } \\
\text { use }\end{array}$ & $\begin{array}{c}\text { Sources of } \\
\text { ignition }\end{array}$ & $\begin{array}{c}\text { Classification of } \\
\text { hazardous waste }\end{array}$ & $\begin{array}{c}\text { Stored } \\
\text { quantity }\end{array}$ \\
\hline & & & $\begin{array}{c}\text { Aggregation } \\
\text { state }\end{array}$ & \\
\hline
\end{tabular}

The risk assessment consists of simplifying health, safety and environmental risks in a simplified manner [6-7]. These steps require more information to be collected than in the hierarchy, regarding the handling conditions of various chemical agents.

First of all, a potential hierarchy of potential risks (PHR) is made, based on the following: quantity, frequency, exposure, and hazard. The hazard class and danger class is then determined using Table 2, [9-11].

Table 2. List of chemical agent released and proposals for classification of hazards [1]

\begin{tabular}{|c|c|c|c|}
\hline \multicolumn{2}{|c|}{ Chemical agents emitted from processes } & \multirow{2}{*}{$\begin{array}{c}\text { VLE } \\
{[\mathrm{mg} / \mathrm{m} 3]}\end{array}$} & \multirow{2}{*}{$\begin{array}{c}\begin{array}{c}\text { The } \\
\text { danger } \\
\text { class }\end{array} \\
2 \\
\end{array}$} \\
\hline \multirow{18}{*}{$\begin{array}{l}\text { Powders } \\
\text { from: }\end{array}$} & Iron & & \\
\hline & Stainless steel alloys & $0,5(\mathrm{Cr})$ & 3 \\
\hline & Aluminum & 10 & 1 \\
\hline & Wood and derivatives & 1 (for cancer) & 4 \\
\hline & Cereals and derivatives & 5 & 2 \\
\hline & Glass fibers & 10 (dust without specific effect) & 2 \\
\hline & $\begin{array}{l}\text { Construction materials (stone, } \\
\text { bricks, beton) }\end{array}$ & 10 (dust without specific effect) & 2 \\
\hline & Metallic plumb & 0,15 (steam) & 4 \\
\hline & Talcum & 10 (dust without specific effect) & 2 \\
\hline & Cement & 10 (dust without specific effect) & 2 \\
\hline & Ceramic fibers & (R40) & 3 \\
\hline & Vegetable fibers & 0,5 & 3 \\
\hline & $\begin{array}{l}\text { Asbestos and materials containing } \\
\text { asbestos }\end{array}$ & (R45) & 4 \\
\hline & $\begin{array}{l}\text { Composite materials } \\
\text { (resin + fiberglass, carbon fibers, ) }\end{array}$ & - & 2 \\
\hline & Painting with plumb & 0,5 (estimate) & 3 \\
\hline & Abrazive discs & 0,1 (estimate) & 3 \\
\hline & Sanding & 0,1 (estimate) & 3 \\
\hline & Graphite & 2 & 2 \\
\hline \multirow{7}{*}{$\begin{array}{l}\text { Fumes } \\
\text { from: }\end{array}$} & The burning treated wood & - & 2 \\
\hline & The welding iron & 5 & 2 \\
\hline & Foundry of metal & - & 2 \\
\hline & Stainless welding & $0,5(\mathrm{Cr})$ & 3 \\
\hline & Foundry and process of plumb & 0,15 & 4 \\
\hline & $\begin{array}{l}\text { The welding and thermoforming of } \\
\text { plastics }\end{array}$ & - & 2 \\
\hline & Vulcanization & - & 4 \\
\hline Vapors & Materials of vegetable or animal & - & 2 \\
\hline
\end{tabular}




\begin{tabular}{|c|c|c|c|}
\hline \multirow{7}{*}{$\begin{array}{l}\text { and } \\
\text { gases } \\
\text { from: }\end{array}$} & origin & & \\
\hline & The tar and embers & 0,2 (R45) & 4 \\
\hline & The heating equipment & $55(\mathrm{CO})$ & 2 \\
\hline & Mercury & 0,05 (steam) & 4 \\
\hline & The processing oils & 19 (INRS) & 3 \\
\hline & The fuel motors & - & 2 \\
\hline & Benzine (fuel) & It contains benzene & 4 \\
\hline \multirow{3}{*}{$\begin{array}{l}\text { Aerosols } \\
\text { come } \\
\text { from: }\end{array}$} & For cutting oils & 1 (INRS) & 3 \\
\hline & The pickling water jet & - & 2 \\
\hline & Oils of stripping & - & 2 \\
\hline
\end{tabular}

\section{Risk assessment chemical inhalation}

In order to establish objectives of this paper, dangers of each chemical agent that occurs in the process and exposure conditions will be account. Exposure after analyzing workload is estimated by:

- physico-chemical properties (volatility);

- handling conditions (process, temperature, etc.);

- the collective safeguards (ventilation);

Risk assessment involves observing and analyzing real work load for each group of welders analyzed consists in reviewing the different tasks carried out, their duration and their chemical agents.

To be meaningful, the analysis should be carried out together with operators to benefit from their experience. Further risk score can be established. Each chemical agent score is determined, depending on the hazard class (Table 2) who has been assigned in PHR stage and presented in table 3 [4].

Table 3. Determination of score of danger by danger class

\begin{tabular}{|c|c|}
\hline The hazard class & Danger score \\
\hline 5 & 10000 \\
\hline 4 & 1000 \\
\hline 3 & 100 \\
\hline 2 & 10 \\
\hline 1 & 0 \\
\hline
\end{tabular}

Volatility class can be determined. Any chemical agent (CA) may be present in 3 aggregation states: solid (pulverulent, fibrous), liquid or gaseous. Each CA is assigned a volatility class based on the aggregate state, and then a score as follows:

- $\quad$ pulverized (solid) materials can be assigned a volatility class of 1 to 3 (Table 4);

- determining the volatility class of a liquid CA requires knowing the approximate use temperature and its boiling temperature in degrees Celsius.

The volatility class is determined using the diagram presented in Figure 1. Products in paste form and those whose ignition temperature is not indicated are assigned the volatility class 3 ;

gasses are assigned the volatility class 1 , regardless of the temperature of use.

Table 4. Determination of powdered AC class volatility [1]

\begin{tabular}{|l|c|}
\hline \multicolumn{1}{|c|}{ Description solid materials } & The class volatility \\
\hline $\begin{array}{l}\text { The material is in the form of fine powder, forming } \\
\text { the powder remaining in suspension in the air } \\
\text { during manipulation }\end{array}$ & 1 \\
\hline
\end{tabular}




\begin{tabular}{|c|c|}
\hline $\begin{array}{l}\text { The material in the form of a powder consisting of } \\
\text { granules }(1-2 \mathrm{~mm}) \text {, form powders which are } \\
\text { deposited rapidly during manipulation }\end{array}$ & 2 \\
\hline $\begin{array}{l}\text { The material is in the form of tablets, granules, } \\
\text { scales (from } 1 \mathrm{~mm} \text { up to } 1 \text { or } 2 \mathrm{~cm} \text { ) slightly friable } \\
\text { less emitting particulates during manipulation } \\
\text { (sugar cubes, granular plastic materials) }\end{array}$ & 3 \\
\hline
\end{tabular}

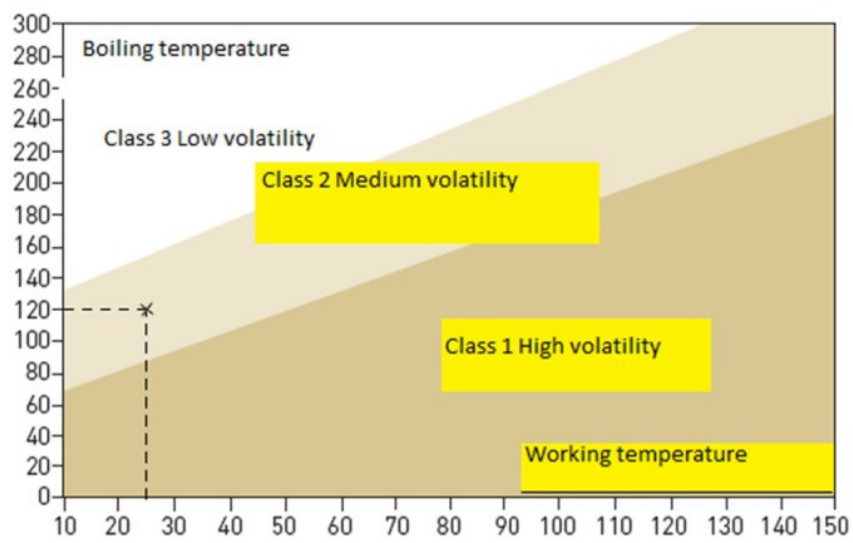

Fig. 1. Determination of liquidity volatility class

The volatility score is then determined. Each volatility class is assigned a score to be used for exposure estimation (Table 5).

Table 5. Score attributed volatility of volatility classes [1]

\begin{tabular}{|c|c|}
\hline The class volatility & The volatility score \\
\hline 1 & 100 \\
\hline 2 & 10 \\
\hline 3 & 1 \\
\hline
\end{tabular}

In the following, the process score is determined. The type of process in which CA is used is determined as indicated in Table 6. A score is assigned to each type of process. In this operation, the most delicate task is to assign a process class by distinguishing between two types of processes, namely:

- processes called "dispersive" which are characterized by an important source of dust, smoke or vapor. By way of example, this type of process corresponds to cutting or welding operations, application of spray products, cleaning of parts in baths with totally discovered solvents;

- the "open" processes, which, by design, are clearly less emissive than dispersive processes. This type can be assimilated to printing machines, presses for metals or plastics, etc

Table 6. Class determination process and the associated score [1]

\begin{tabular}{|c|c|c|c|}
\hline Dispersion & Open & $\begin{array}{c}\text { Closed but opened } \\
\text { regularly }\end{array}$ & $\begin{array}{c}\text { Closed } \\
\text { permanently }\end{array}$ \\
\hline
\end{tabular}




\begin{tabular}{|c|c|c|c|}
\hline $\begin{array}{l}\text { Eexamples: } \\
\text { Painting the pistol } \\
\text { manually emptying } \\
\text { sacks of } \\
\text { Arc welding } \\
\text { Manual cleansing } \\
\text { material, using } \\
\text { portable machines } \\
\text { (Robots,etc.) }\end{array}$ & $\begin{array}{l}\text { Examples: } \\
\text { Reactors, mixers } \\
\text { open painting the } \\
\text { brush, conditioning } \\
\text { stations } \\
\text { (Drums,etc. ) } \\
\text { overseeing printing } \\
\text { machines }\end{array}$ & $\begin{array}{l}\text { Examples: } \\
\text { Chemical reactors } \\
\text { closed to regular AC } \\
\text { loads, taking } \\
\text { samples, machinery } \\
\text { degreasing liquid or } \\
\text { vapor phase. }\end{array}$ & $\begin{array}{l}\text { Examples: } \\
\text { Chemical reactor }\end{array}$ \\
\hline Class 4 & Class 3 & Class 2 & Class 1 \\
\hline \multicolumn{4}{|c|}{ Score procedures } \\
\hline 1 & 0,5 & 0,05 & 0.001 \\
\hline
\end{tabular}

The technological process list is not exhaustive

The welding process is analyzed in the paper considers a dispersive process, to fit with in class 4 with a score of process equal to 1 .

Taking into account the above elements, the collective protection score is determined. The type of collective protection operating at the station where chemical agent is located is determined by the information shown in Table 7. A score is associated with each class of collective protection means. Then the risk score by inhalation is calculated. For each chemical agent used for a determined load, the inhalation risk score with " $\mathrm{S}_{\text {inh" }}$ is calculated using the following relationship:

$\mathrm{S}_{\text {inh }}=$ score of danger $\mathrm{X}$ score of volatility $\mathrm{X}$ score of process $\mathrm{X}$ score of collective (1) protection

By substituting in relation (1) the values found for the analyzed case result:

$$
\mathrm{S}_{\mathrm{inh}}=1000 \times 1 \times 1 \times 1=1000
$$

Analyzing the relationship (2) a moderate risk results that probably requires the implementation of corrective measures and an important assessment (emissions determination).

Table 7. Determination of collective protection classes and associated scores [1]

\begin{tabular}{l|ll}
$\begin{array}{c}\text { Absence of } \\
\text { mechanical } \\
\text { ventilation } \\
\text { emission source }\end{array}$ & $\begin{array}{l}\text { Removing worker from the Presence of mechanical } \\
\text { ventilation }\end{array}$ \\
\hline Gas exhaust hood & Suction slot & Clasa 3, score $=0,7$ \\
\hline Class 2, score $=0,1$ &
\end{tabular}




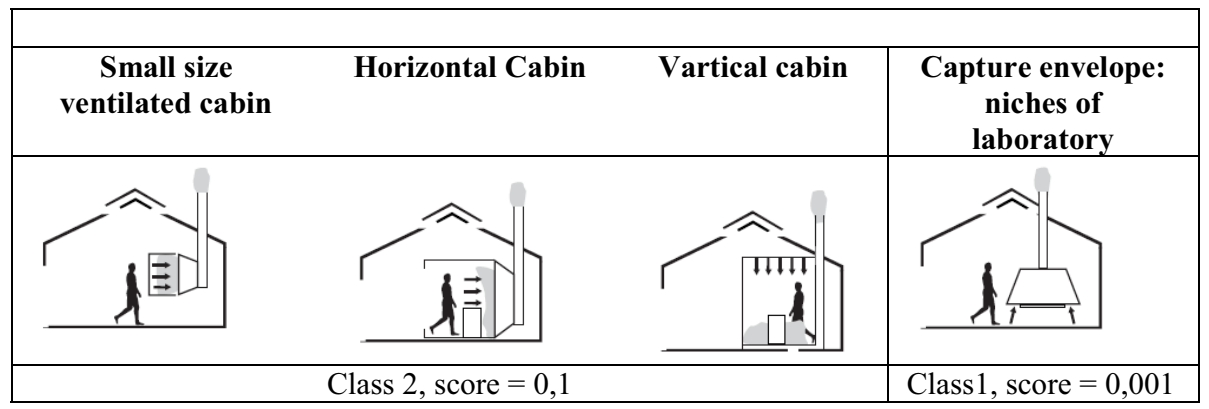

Finally, the risk characterization can be done. The risk of each task is characterized by the decision grid shown in Table 8.

Table 8. Risk characterization grid for inhalation and skin

\begin{tabular}{|c|c|l|}
\hline $\begin{array}{c}\text { The risk } \\
\text { score }\end{array}$ & $\begin{array}{c}\text { The priority } \\
\text { action }\end{array}$ & The risk characterization \\
\hline$\geq 1000$ & 1 & Very probable risk that requires immediate corrective action \\
\hline $100-1000$ & 2 & $\begin{array}{l}\text { Moderate risk requiring probably implementing corrective } \\
\text { actions and a thorough evaluation (determination of } \\
\text { pollutants) }\end{array}$ \\
\hline$<100$ & 3 & At low risk does not require modifications \\
\hline
\end{tabular}

\section{Conclusions}

- as a result of the determinations made in the steel production hall in different work areas, at the respiratory level it was found that the value of the concentrations of inhalable powders, aerosols and fumes from different metals exceeds the CMA value of the Order 1957/1995, in different places of measurement and in different proportions;

- the determination of the potential risk of welding was done starting from the quantity class, thus determining: the frequency of use class (which is 4); the hazard class (which is 100,000); the priority class (which is high), resulting in a potential risk of large welding;

- inhalation risk assessment was done by following the steps: workload analysis; determining the hazard score according to the hazard class (if analyzed: hazard class $=3$ and hazard score $=100$ ); volatility class and volatility grade (here is 100$)$; determining the process score (which in the case being analyzed is 1.00); determining the collective protection score; calculating the risk score by inhalation (which in this case is $=1000$ ), corresponding to a moderate risk;

\section{References}

1. Gh. Amza, Ecotechnology (Printech Publishing House, 2007)

2. Gh. Amza, Ecotechnology and sustainable development (Printech Publishing House, 2009)

3. Gh. Amza, Treaty of materials technology, (Academia Romană Publishing House, 2002)

4. Gh.Amza, M.Parvulescu, TQSD, 258 (2008)

5. Gh. Amza, Materials technology, IV, (BREN Publishing House, 2003)

6. V. Ionescu, Buletinul Stiintific UPB Seria D, 2, 85 (2016)

7. V. Ionescu, Gh.Calea, Gh.Amza, G.Iacobescu, D. Nitoi, A. Dimitrescu, International Scientific Conference SAMRO, 145, (2016) 
8. R. E. Knowlton, An introduction to Hazard and Operability Studies - the Guide Word Approach, (Chemetics, Vancouver, BC, 1986)

9. Agenţia Europeană pentru Substanţe Chimice (ECHA), Page dedicated to the use of chemicals safe at work, http://echa.europa.eu/ro/use-chemicals-safely-at-work

10. Agenţia Europeană pentru Securitate şi Sănătate în Muncă, theme dangerous substances, https://osha.europa.eu/ro/topics/ds

11. Inspecţia Muncii, Page dedicated to IMM, professional chemical risks, http://www.inspectiamuncii.ro/ssmimm/plb.html 